\title{
Temporal Patterns in Ceramic Production in the Berbati Valley, Greece
}

\author{
Ian K. Whitbread \\ University of Leicester \\ Leicester, England \\ Matthew J. Ponting \\ University of Liverpool \\ Liverpool, England

\section{Berit Wells} \\ Swedish Institute at Athens \\ Athens, Greece
}

This research explores temporal patterns in the procurement of raw materials for ceramic production, based mainly on material recovered in regional survey. The underlying premise is that potters in different cultural phases will preferentially exploit the same geological landscape for the most suitable raw materials, but different materials may be preferred depending upon the potters' technological traditions. A program of petrographic and chemical analyses was carried out on ceramics from the Berbati-Limnes Archaeological Survey, Argolid, Greece. Ceramic fabrics were studied from several cultural phases and compared with patterns of settlement within the valley. The results show that ceramics from regional surveys can be used to identify broad patterns of change in exploitation of the same landscape. In some cases these patterns correlate with changes in settlement and may indicate that different choices in raw material procurement mark the arrival of potters from outside the valley.

\section{Introduction}

Regional surveys are primarily designed to explore changes in settlement patterns and social interactions with the landscape. To achieve these goals most surveys rely on ceramics to date occupation evidence, to classify sites into broad functional categories (Alcock 2000; Foxhall 2004), and to identify regional contacts based on the distribution of wares. Compositional analysis is another aspect of ceramic evidence, but one that regional surveys have generally underutilized. It offers valuable insights into ancient landscape exploitation through raw material acquisition and use. This study investigates temporal patterns of raw material procurement based mainly on ceramic fabrics from the Berbati-Limnes Archaeological Survey (Wells 1996a) in the Argolid region of the Peloponnese, southern Greece (FIG. I). Our goal was to determine whether the same raw materials were exploited throughout the occupation of the Berbati Valley or whether different material choices accompanied changes in settlement patterns.
Raw materials for ceramic production are primarily geological in origin and their occurrence within a landscape is likely to have changed little during the period of human occupation. This assumption of constant availability underlies most provenance and technological studies of ancient ceramics, though there may be exceptions, such as fresh alluvial deposition or exhaustion of exposed materials by potters. It is also likely that some raw materials within a landscape are better suited for pottery production than others and that over time potters' preferences in exploiting these resources would have been embedded in the local technological traditions that were passed down through learning networks (Gosselain 1998). In such cases the fabrics of locally-produced ceramics might show a high degree of uniformity except for technological or functional variation, such as in the production of handmade or wheelthrown wares, cooking wares or table wares.

Alternatively, it is possible that changes in the way potters exploited the landscape could produce distinct differ- 
Table 1. Chronological overview of settlement and kiln evidence in the Berbati Valley. The main periods of occupation are in uppercase and fewer finds from other periods suggest either limited occupation or settlement nucleation.

\begin{tabular}{|llc|}
\hline $\begin{array}{l}\text { Approximate } \\
\text { end date }\end{array}$ & Period & Kiln \\
\hline A.D. 2000 & MEDIEVAL-MODERN & X \\
A.D. 700 & LATE ANTIQUE & X \\
A.D. 500 & LATE ROMAN & - \\
A.D. 300 & Early Roman & - \\
100 в.c. & HELLENISTIC & - \\
300 в.c. & CLASSICAL & X \\
600 в.c. & ARCHAIC & - \\
800 B.c. & Geometric & - \\
1000 в.C. & Protogeometric & - \\
1100 в.c. & LATE HELLADIC & X \\
1600 в.C. & Middle Helladic & - \\
2100 в.C. & Early Helladic III & - \\
2400 в.C. & EARLY HELLADIC II & - \\
3000 в.C. & EARLY HELLADIC I & - \\
3300 в.c. & FINAL NEOLITHIC & - \\
4600 в.C. & Late Neolithic & - \\
5400 в.c. & Middle Neolithic & - \\
\hline
\end{tabular}

ences in fabric composition, even where the range of geological resources was limited. Different ceramic traditions may have favored different types of resources and the arrival of new potters within a landscape might be reflected in a change of procurement practices. Broader social constraints may also have influenced raw materials selection. Ethnoarchaeological research has demonstrated the effects, for example, that access rights can have on pottery compositions (Neupert 2000; Stark, Bishop, and Miksa 2000). This means that the raw materials within a modern landscape may not always have been considered viable resources in the past. Continuity and change in the use of raw materials can therefore reflect social issues in landscape exploitation, and regional surveys offer the best opportunities to explore such changes in different cultural phases.

\section{The Berbati-Limnes Archaeological Survey}

The Berbati Valley (140-300 masl) is situated east of the Bronze Age citadel of Mycenae in the mountainous border zone between the key regions of the Argolid and Corinthia in the NE Peloponnese (FIG. I). The modern village of Prosimna (formerly Berbati) is positioned at the eastern end of the main valley (FIG. 2), with the village of Limnes located still further east, high in the mountains. Access is primarily from the Argolid, through the Klisoura Pass or via Mycenae, but Limnes is more accessible from the Corinthia.

The survey was carried out between 1988 and 1990 and produced evidence for human use of the valley from the Palaeolithic to A.D. 1700. Of interest for our purposes are the varied settlement patterns through time in the valley, including discontinuous occupation, settlement dispersal, and nucleation (TABLE I) (Wells 1996a; Penttinen 2005: 12), and the possibilities these offered for identifying cultural transitions during which potters with different traditions of raw materials selection might have entered the landscape. Defining a lack of occupation through negative evidence requires considerable caution (Alcock 1993: 53-55). The position of the valley in a mountainous boundary zone does, nevertheless, increase the likelihood of interrupted settlement. Although the valley is currently within the Argolid, it may have belonged to the Corinthia (FIG. I) at other times, and was probably treated as marginal land at all times. It was perhaps used for pastoralism, or in later times, by people living beyond the state, since the borders were not defined until Classical-Hellenistic periods when birthplace became relevant for political and social rights (Penttinen 2005: 98).

Equally important is the discovery of physical evidence for ceramic production in the valley, providing secure reference material for local fabrics. A Late Bronze Age (mainly Late Helladic II) pottery kiln at the previously-excavated site of the Mastos (FIG. I, TABLE I) (Åkerström 1968) provided control groups for chemical analyses of Mycenaean fineware (Hein, Tsolakidou, and Mommsen 2002), which was widely traded around the eastern Mediterranean. The survey found evidence for pottery production elsewhere in the valley during the Classical and Modern periods, and recent excavations by the Greek Archaeological Service found production evidence from the Late Antique period in the center of the valley, west of the villa rustica area (findspots FS 500-504) (FIG. I). The evidence for local ceramic production in different periods and for changes in occupation of the valley enhanced the possibility that ceramics from the survey would reflect different traditions of ceramic production operating within the same landscape.

Unfortunately, there are significant problems in using survey materials for ceramic analysis. Surface collection can produce chronologically and functionally undifferentiated groups of material, further complicated by the fragmentation, weathering, and abrasion of ceramic remains (Millett 2000). Ceramic fabrics are little affected by exposure, which has prompted widespread hand-specimen studies of the fresh breaks in sherds as a means of classifying and quantifying large quantities of survey pottery (van Dommelen 2000; Moody et al. 2003). Hand-specimen analysis can be very effective when used in this way but the accuracy and precision of inclusion identification is too poor for an investigation of raw materials. Petrographic analysis of 

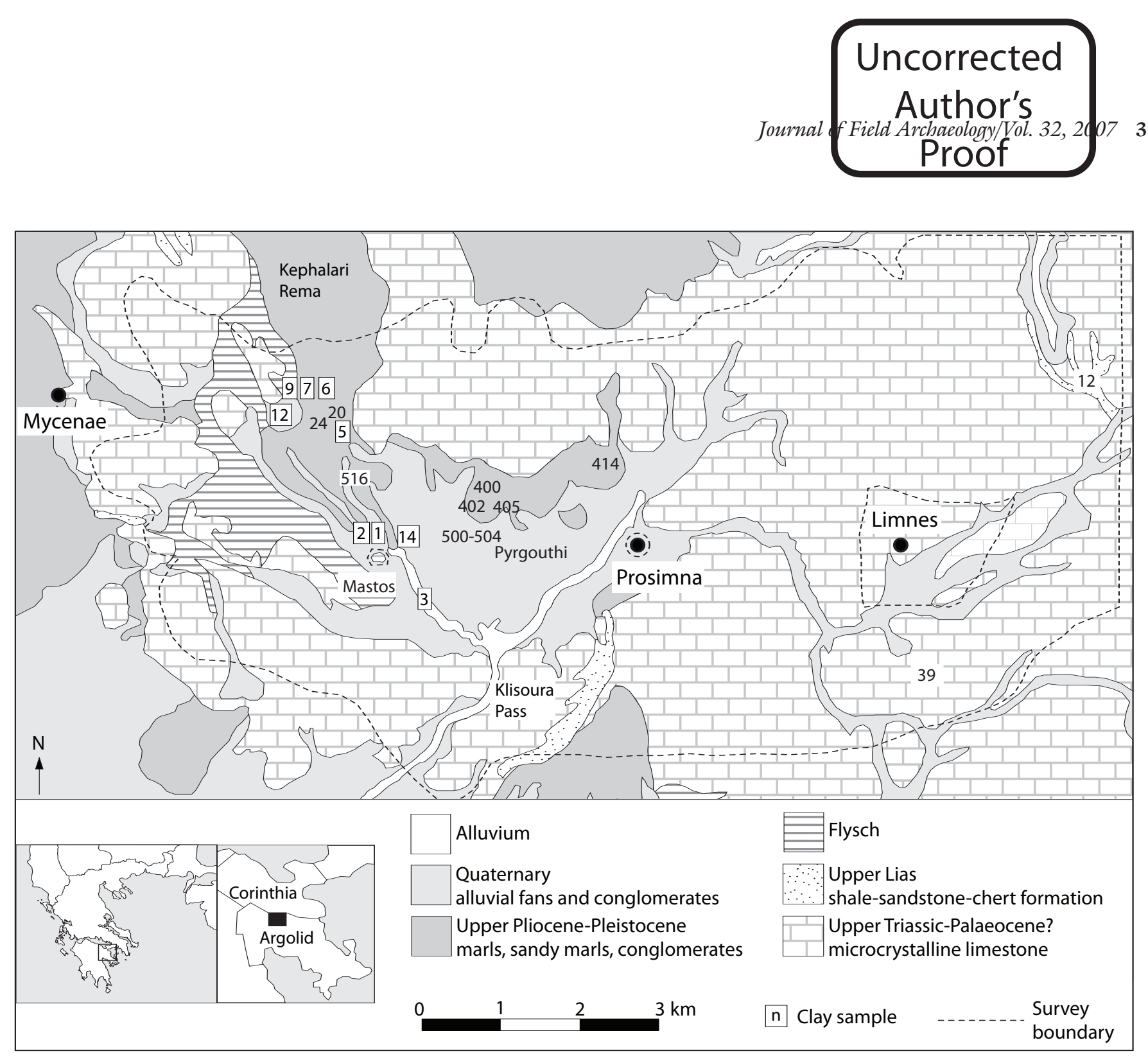

Figure 1. Geological map of the Berbati-Limnes Archaeological Survey area (after Tataris et al. 1970)

showing only those findspots referred to in the text. For full findspot distributions see Wells 1996a fig. 1.

ceramics in thin section (mounted on a glass slide and ground to a thickness of $0.03 \mathrm{~mm}$ ) by means of a polarizing microscope offers far greater analytical resolution because mineral and rock fragments can be accurately identified and attributed to geological resources.

Such laboratory-based analyses of ceramics are common in provenance studies (Jones 1986) but have rarely been reported from survey projects in Greece (Matson 1972; Kiriatzi 2003). This is probably due in part to the limited number of samples that can be analyzed because of sample preparation and analytical costs. Differences in research strategies between provenance studies and regional surveys may also be a limiting factor. The former requires tight control over attributions such as diagnostic pieces, stratified contexts and production sites to construct the cultural framework necessary for interpreting fabric variation. Rarely can survey material alone provide such control. In an attempt to overcome these problems, the current study focused on identifying broad trends in fabric variation over several cultural periods rather than on trying to establish a comprehensive fabric classification. Any patterns arising from the study could then be explored in the future through additional sampling and analysis.

Between seven and 64 pottery samples were selected from each cultural period defined in the survey publication (Wells 1996a) for the purpose of cross-period fabric comparisons. Sample selection was affected by differences in knowledge of the local ceramic repertoire for each period. Furthermore, some samples were re-allocated to different periods as a result of new evidence arising from post-survey excavation projects. So far as possible the sampled ceramics reflect a range of functions (e.g., for cooking, drinking, storage, and transport) in case different fabrics were used for different purposes. Similar ceramic shapes were al- 


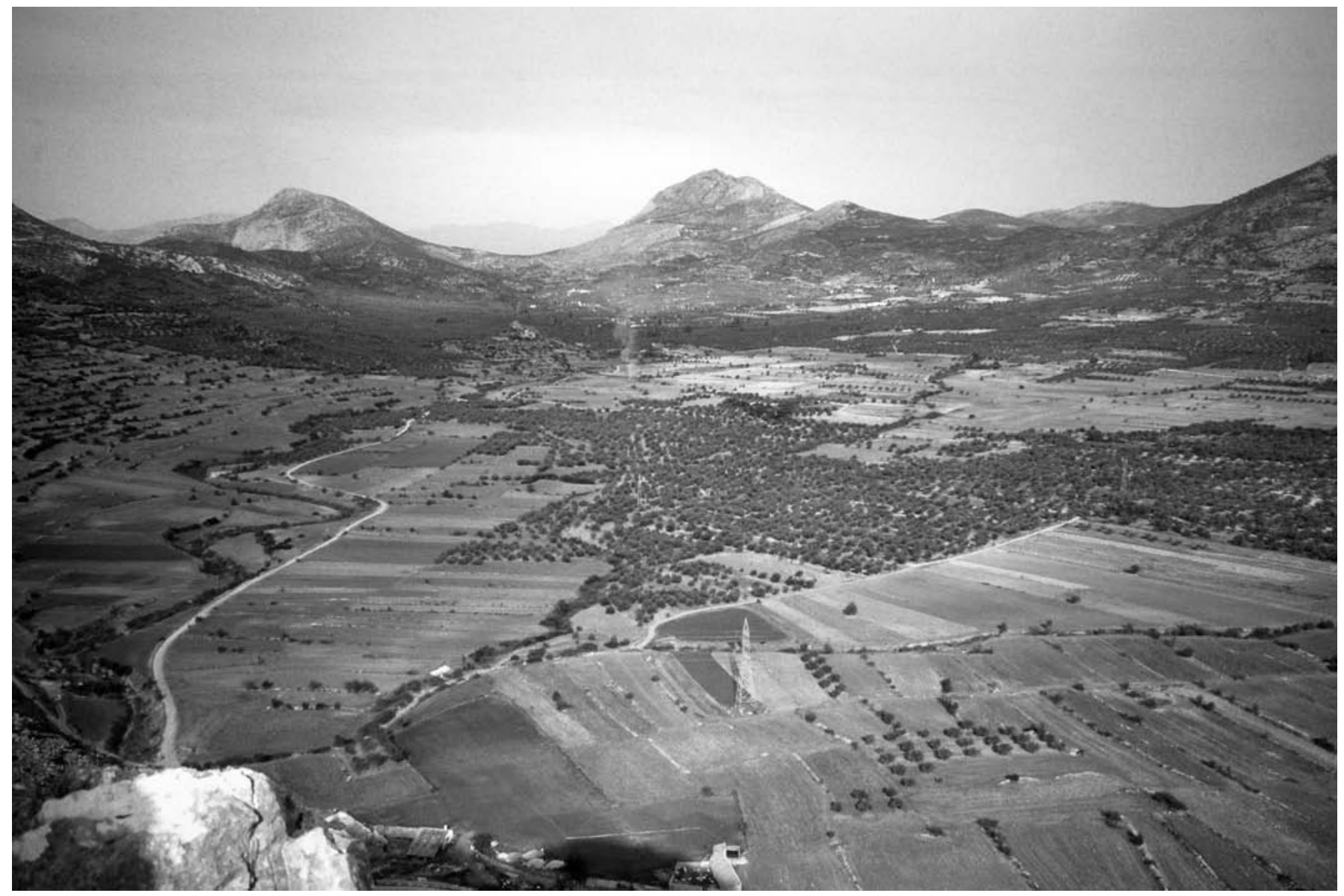

Figure 2. View of the Berbati Valley from the mountains south of Prosimna, looking west (Photograph: Berit Wells).

so sought across cultural periods to help identify broad trends in raw materials procurement for vessels of the same type, (e.g., tile, amphora, pithos [pl. pithoi]), cooking pot, basin, bowl, jar, jug, krater, lekane, skyphos, cup, figurine and loom weight), although no one ceramic shape was present throughout the chronological range of the study.

The wide chronological range and limited quantities of diagnostic survey material, especially from periods of sparse or intermittent occupation, made it difficult to acquire a representative range of fabrics from each period. Although survey finds were the main source of samples, supplementary material came from the Mastos excavations (Säflund 1965), post-survey excavations at the Pyrgouthi farmstead (findspot FS 506) (Penttinen 2005, Hjohlman 2005) and excavations of the later cult remains at a Mycenaean tholos tomb (Wells, Ekroth, and Holmgren 1996). Excavated ceramics filled some chronological gaps in the study, but did not alleviate all problems arising as they are discontinuously spread across the chronological range.

\section{Analytical methods}

Results from the analysis of 233 ceramic thin sections (TABLE 2) are reported here. These samples were studied petrographically using a Leitz Laborlux 12 polarizing microscope. They were also characterized in terms of clay color. Aegean potters commonly used combinations of calcareous and non-calcareous clays (Whitbread 1995: 390), which were generally correlated with yellow- and red- colored fabrics respectively. Variations in ancient firing conditions (mainly temperature and atmosphere) may mask the underlying yellow and red distinctions, but this variation was eradicated by refiring all of the pottery samples under controlled conditions at a temperature higher than the original firings, in this case at $1000^{\circ} \mathrm{C}$ for one hour in an oxidizing atmosphere. The "fired" color of a pottery sample therefore refers to its appearance when sampled, but its "refired" color refers to its appearance after being fired again in the laboratory. 


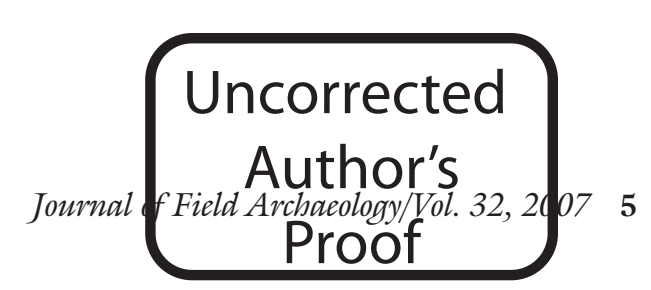

Table 2. Petrographic groups and classes distributed by chronological period. The number of samples that refired red or yellow is shown below the Total row.

\begin{tabular}{|c|c|c|c|c|c|c|c|c|c|c|c|c|c|c|c|}
\hline $\begin{array}{l}\text { Group } \\
\text { Class }\end{array}$ & $\begin{array}{l}\text { Clay sample } \\
\text { nos. }\end{array}$ & Neolithic & $E H I$ & EHII & EHIII & $M H$ & $L H$ & Geometric & Archaic & Classical & $\begin{array}{l}\text { Hellenistic } \\
\text { E. Roman }\end{array}$ & Roman & $\begin{array}{l}\text { Late } \\
\text { Antique }\end{array}$ & $\begin{array}{l}\text { Medieval } \\
\text { Modern }\end{array}$ & $\begin{array}{l}\text { Total } \\
\text { samples }\end{array}$ \\
\hline \multicolumn{16}{|l|}{ Felsic } \\
\hline $\begin{array}{l}\text { Chert limestone } \\
\text { garnet }\end{array}$ & $3,12,14$ & 1 & - & - & - & - & - & - & - & - & - & 11 & 19 & 1 & 32 \\
\hline Quartz limestone & - & 4 & 1 & - & - & - & - & - & - & 2 & - & 3 & - & 1 & 11 \\
\hline Fine sand & - & - & - & - & - & - & - & - & - & 3 & 2 & 2 & 1 & 1 & 9 \\
\hline Very fine sand & - & - & - & - & - & - & - & 7 & 12 & 8 & 4 & 2 & 2 & - & 35 \\
\hline Silt-extremely fine & $1,2,5-7,9$ & & - & - & 3 & 2 & - & 16 & 1 & - & 13 & 3 & - & 2 & 40 \\
\hline \multicolumn{16}{|l|}{ Mudstone } \\
\hline Chaff & - & - & - & - & - & - & 2 & - & - & - & - & - & - & - & 2 \\
\hline Limestone & - & - & - & 1 & 1 & 1 & - & - & - & - & - & 1 & 4 & - & 8 \\
\hline Siltstone limestone & - & - & - & 4 & - & - & - & - & - & - & 1 & - & - & 1 & 6 \\
\hline $\begin{array}{l}\text { Quartz sand and } \\
\text { breccia } \\
\text { Fine sand }\end{array}$ & - & - & - & - & - & - & - & - & 2 & - & - & - & - & - & 2 \\
\hline extremely fine matrix & - & - & 1 & 1 & 3 & 6 & 1 & 1 & 1 & 15 & 4 & - & 4 & - & 37 \\
\hline \\
\hline $\begin{array}{l}\text { sandy } \\
\text { Sparse in very fine }\end{array}$ & - & - & - & - & - & - & - & - & - & - & - & - & 4 & - & 4 \\
\hline sand matrix & - & 9 & 5 & 1 & - & - & - & - & - & - & 3 & - & 1 & 4 & 23 \\
\hline \multicolumn{16}{|l|}{ Clay-pellet } \\
\hline $\begin{array}{l}\text { Highly calcareous } \\
\text { Red silty clay- }\end{array}$ & - & - & - & - & - & - & - & - & - & 2 & - & - & - & - & 2 \\
\hline $\begin{array}{l}\text { pellets } \\
\text { Red clay-pellets in }\end{array}$ & - & - & - & - & - & - & - & - & - & - & - & - & 1 & 3 & 4 \\
\hline $\begin{array}{l}\text { silty matrix } \\
\text { Large fine clay- }\end{array}$ & - & - & - & - & - & - & - & - & - & 1 & - & 2 & - & - & 3 \\
\hline pellets & - & - & - & - & - & - & - & - & - & - & - & - & 10 & - & 10 \\
\hline \multicolumn{16}{|l|}{ Volcanic } \\
\hline $\begin{array}{l}\text { Cryptocrystalline } \\
\text { with phenocrysts }\end{array}$ & - & - & - & 1 & - & - & - & - & - & - & - & - & - & - & - \\
\hline Silicified? & - & 2 & - & 1 & - & - & - & - & - & - & - & - & - & - & - \\
\hline Fresh well-sorted & - & - & 1 & - & - & - & - & - & - & - & - & - & - & - & - \\
\hline Total Samples & 9 & 16 & 8 & 12 & 6 & 7 & 19 & 9 & 15 & 44 & 17 & 21 & 46 & 13 & 233 \\
\hline \multicolumn{16}{|l|}{ Refiring Results } \\
\hline Red & 6 & 16 & 8 & 8 & 3 & 2 & 2 & 5 & 13 & 22 & 14 & 21 & 25 & 10 & 149 \\
\hline Yellow & 3 & - & - & 4 & 3 & 5 & 17 & 4 & 2 & 22 & 3 & - & 21 & 3 & 84 \\
\hline
\end{tabular}

Chemical analyses are more effective than microscopy for studying fineware fabrics, especially in comparison with fine-grained clay samples. Moreover, the method provides further insight into the use of calcareous and non-calcareous clays. Out of the pottery samples studied by petrography 70 pieces were prepared for chemical analysis. These samples were removed from the sherds using a diamond-impregnated drill. The powder was oven dried at $105^{\circ} \mathrm{C}$ and $30 \mathrm{mg}$ from each sample was weighed into a platinum crucible, mixed with $90 \mathrm{mg}$ of lithium metaborate, and fused in a muffle furnace at $1050^{\circ} \mathrm{C}$ for $25 \mathrm{~min}$ utes. The fused bead was dissolved in dilute nitric acid. Analysis was conducted by inductively-coupled plasma atomic emission spectrometry (ICP-AES) on a Perkin Elmer P400 instrument.

The instrument was calibrated for 18 elements $(\mathrm{Na}, \mathrm{Mg}$, $\mathrm{Al}, \mathrm{Si}, \mathrm{K}, \mathrm{Ca}, \mathrm{Sc}, \mathrm{Ti}, \mathrm{V}, \mathrm{Cr}, \mathrm{Mn}, \mathrm{Fe}, \mathrm{Co}, \mathrm{Ni}, \mathrm{Zn}, \mathrm{Sr}, \mathrm{La}$, and
Ce) using two multi-element standards prepared from commercial analytical single element solutions and matrixmatched. Instrumental drift was monitored using similar solutions inserted every 10 samples. Standard reference material (IAEA Soil 7), prepared like the pottery samples, was included at the beginning and end of each batch. Instrumental precision is generally $\mathrm{l}$ to $3 \%$ relative, with this figure increasing as the respective detection limits are reached. Figures calculated on replicate analyses of the multi-element standard reference materials across all the analyses are more realistic (Heyworth et al. 1991) than manufacturers' specifications, especially given the dissolution complexities of ceramics and glass (Potts 1987: 183). Calculated in this way, the average precision of analysis for the major elements ( $>1 \%$ ) is $5 \%$, for minor elements ( $>$ 100 parts-per-million [ppm] $)$ is $7 \%$, and for trace elements $(<100 \mathrm{ppm})$ is $23 \%$. Estimated against the certified val- 
ues for the standard reference material, the average error for the major elements is $2 \%$, for the minor elements is $3 \%$, and for trace elements is $10 \%$, though trace element accuracy will become significantly poorer approaching detection limits. Accuracy figures achieved here were consistent with other studies (Heyworth et al. 1991).

\section{Geology of the Berbati Valley}

Materials analysis works best in regions of diverse geology, e.g. with igneous, metamorphic and sedimentary units, but the Berbati Valley is predominantly sedimentary (FIG. I) (Tataris et al. 1970), reflecting a regional geology commonly encountered in mainland Greece. The mountains surrounding the valley are composed of crystalline limestones with intercalations of cherts, marls, and occasionally dolomites. Shales and related rocks occur sporadically as part of the shale-sandstone-chert formation and in undivided flysch situated at the western end of the valley, consisting of shales, reddish marls, sandy marls, sandstones, conglomerates, and clastic limestones. The NW area of the valley, along the Kephalari Rema, is filled with Upper Pliocene-Pleistocene marls, sandy marls, and conglomerates. Quaternary cemented conglomerates dominate the eastern part of the valley floor and much of the central area of the valley is covered with Quaternary alluvial fans.

Calcareous rocks and sediments (limestones and marls) dominate the regional geology, especially in the NW, where many archaeological sites are located (Wells 1996a, fig. 5). The most distinctive non -calcareous rocks are shale, sandstone, and chert, notably from the shale-sandstone-chert formation and the undivided flysch. Volcanic rocks are reported from the lower parts of these formations, but were not identified in the field nor marked on a 1:50,000 scale geological map (Tataris et al. 1970).

The valley is not large in terms of the clay procurement patterns suggested by Arnold's (1985: 50) ethnographic study, where $33 \%$ of potters collected clays within $1 \mathrm{~km}$, and $84 \%$ within $7 \mathrm{~km}$ of their bases. Spatially significant fabric distribution was not anticipated (and was not evident in the results) and fabric differences were consequently attributed to potters' technical and personal preferences in raw materials, restrictions in the viability of specific resources at different times, and the potential presence of imported pottery.

Nine clay samples were collected in the valley to represent potential raw materials (FIG. I, TABLE 2). Selection criteria were based on the degree of clay plasticity and the aim of acquiring both yellow- and red-firing clays. Clay sampling focused on the central and Nw parts of the valley where remains of occupation are most evident. Few de- posits were found amongst the alluvial fans and conglomerates that dominate the center of the valley. These were Clay Samples 1, 2 and 14 from near the Mastos where the Late Helladic kiln is located and Clay Sample 3 from a deep gully cutting the Quaternary alluvial fans to the east of this site. Despite ranging from pale brown to dark reddish brown in the field, all of these samples fired red. Clay Samples 5, 6 and 7 came from Pliocene-Pleistocene sediments in the Kephalari Rema ravine. They are naturally extremely fine grained and fired yellow. Clay Samples 9 and 12 (the latter from terra rossa soils), which also came from this region, fired red. The nine clay samples were prepared as briquettes, and were fired and sampled in the same manner as ceramics for both microscopic and chemical analyses.

\section{Petrographic Results}

Seven fabric groups were defined, based broadly on geological composition. These were subdivided into classes forming basic compositional and technological units (TABLE 2). The best-defined groups were called "Volcanic", "Mudstone," "Sandstone," "Felsic" (having quartz and feldspar) and "Clay-pellet." "Calcareous sand" (nine samples) and "Grog" (crushed pottery inclusions; two samples) groups were also identified, but were very small and are not considered further in this discussion. Likewise, three Felsic and three Sandstone fabric classes are not discussed here as they were composed of only one or two samples in each case. The Volcanic group is small and probably includes imported ceramics, given the apparent absence of volcanic rocks in the valley. The Mudstone (including siltstone and mudstone breccia) (Whitbread 1995: 334-336) and Sandstone groups contain well-defined classes but display some overlap with the Felsic group. Felsic is a catchall group, since most fabrics contain quartz/feldspar. Felsic classes were primarily defined by grain-size differences and the presence of chert and limestone.

Where sampled shapes could be securely attributed to broad functional categories these are compared with the petrographic fabric groups and classes in Table 3. No fabric group is specific to a particular function, and likewise fabric classes are commonly distributed across functional categories. Felsic fabrics appear in all functional categories. Fine-grained Felsic fabrics are particularly common in drinking vessels, whereas Felsic (classes: chert limestone garnet and quartz limestone) fabrics are present in open and closed vessels, and in transport and cooking wares. Mudstone fabrics are present across a similarly wide range of functions, except for the lack of Mudstone in transport vessels. Mudstone fabrics are notably common in open and storage vessels, mainly pithoi, and tiles. Sandstone fabrics are most common in open vessels, but absent in building 


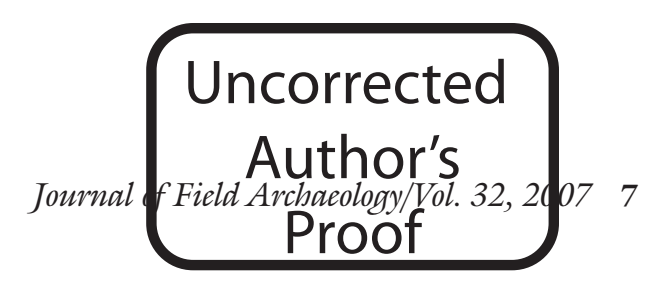

Table 3 Petrographic fabric groups and classes distributed by broad functional categories comprising nine or more samples.

\begin{tabular}{|c|c|c|c|c|c|c|c|c|c|c|}
\hline Group & Drinking & Open & Closed & Storage & Transport & Cooking & Building & Tile & Kiln & Total \\
\hline \multicolumn{11}{|l|}{ Felsic } \\
\hline $\begin{array}{l}\text { Chert limestone } \\
\text { garnet }\end{array}$ & - & 11 & 5 & 1 & 6 & 5 & - & - & - & 28 \\
\hline Quartz limestone & - & 4 & 1 & - & 1 & 2 & 2 & - & - & 10 \\
\hline Fine sand & - & 4 & - & - & 1 & 2 & - & - & - & 7 \\
\hline Very fine sand & 14 & 9 & 2 & - & 1 & - & - & 3 & 1 & 30 \\
\hline $\begin{array}{l}\text { Silt-extremely fine } \\
\text { sand }\end{array}$ & 15 & 4 & 2 & - & - & - & 1 & - & 2 & 24 \\
\hline \multicolumn{11}{|l|}{ Mudstone } \\
\hline Chaff & - & - & - & - & - & - & 2 & - & - & 2 \\
\hline Limestone & - & 2 & - & 2 & - & - & 1 & 2 & - & 7 \\
\hline Siltstone limestone & - & 2 & - & 1 & - & 2 & - & - & - & 5 \\
\hline breccia & - & - & - & - & - & 2 & - & - & - & 2 \\
\hline $\begin{array}{l}\text { Fine sand- } \\
\text { extremely fine } \\
\text { matrix }\end{array}$ & 1 & 10 & 4 & 4 & - & - & 2 & 5 & 4 & 30 \\
\hline \multicolumn{11}{|l|}{ Sandstone } \\
\hline $\begin{array}{l}\text { Red clay pellets- } \\
\text { sandy }\end{array}$ & - & - & - & - & - & - & - & 4 & - & 4 \\
\hline $\begin{array}{l}\text { Sparse in very fine } \\
\text { sand matrix }\end{array}$ & - & 16 & 3 & 1 & 1 & 1 & - & - & - & 22 \\
\hline \multicolumn{11}{|l|}{ Clay-pellet } \\
\hline Highly calcareous & - & - & - & - & - & - & 1 & - & 1 & 2 \\
\hline $\begin{array}{l}\text { Red silty clay- } \\
\text { pellets } \\
\text { Large fine clay }\end{array}$ & - & 1 & - & - & 1 & 1 & - & 1 & - & 4 \\
\hline $\begin{array}{l}\text { Large fine clay } \\
\text { pellets }\end{array}$ & - & - & - & - & - & - & - & 2 & 8 & 10 \\
\hline \multicolumn{11}{|l|}{ Volcanic } \\
\hline Silicified (?) & - & 1 & 1 & 1 & - & - & - & - & - & 3 \\
\hline Total & 30 & 64 & 18 & 10 & 11 & 15 & 9 & 17 & 16 & 190 \\
\hline
\end{tabular}

material (other than tiles), drinking vessels and kiln material. As a result of the small number of samples, the range of functions in the Clay-pellet and Volcanic groups is probably underrepresented, though Clay-pellet (class: large fine clay-pellets) is notable for its presence in kiln and building materials, including tiles. In summary, potters' preferences for raw materials show limited orientation towards specific functions, though this observation is examined below in the context of each cultural phase.

The ceramic fabrics are discussed below by cultural phase, following the periodization used in the Berbati-Limnes survey publication (Wells 1996a). In each case, the discussion focuses on the evidence for occupation in the period (TABLE I) and on the occurrence and range of fabrics as outlined in Table 2.

\section{Neolithic}

Occupation during the Neolithic period was probably intermittent, but chronological resolution is poor and we cannot be certain of this. The 16 samples come from three findspots (FS 39, FS 400, and FS 405), and all have redfiring, non-calcareous clays divided among the Sandstone,
Felsic, and Volcanic groups. The nine Middle Neolithic samples come from FS 400 and belong to Sandstone (class: sparse in very fine sand matrix) (FIG. 3). Proximity to a spring and arable soils may have been responsible for the relatively long-term occupation here (Johnson 1996). Late and Final Neolithic samples (one and four respectively) have Felsic fabrics, notably containing quartz and limestone, consistent with a wider dispersal of subsistence activities in the valley (Johnson 1996). Two Final Neolithic Volcanic (class: silicified?) fabrics may be imported; external contacts are clearly evident in finds of obsidian resembling material from the Aegean island of Melos (Runnels 1996).

\section{Early Helladic}

The most diverse range of fabrics comes from this period, but Early Helladic (EH) I-II material was widely distributed in the valley, possibly reflecting an expansion of settlement. Apparent depopulation in EH III may be due to settlement nucleation at the Mastos (Forsén 1996), the only settlement to supply pottery of this phase.

EH I Sandstone fabrics are similar to the ones in the Ne- 
olithic, particularly four pieces of Talioti ware, characteristic of EH I in the region (Dousougli 1987), which are composed of Sandstone (class: sparse in very fine sand matrix). EH I-II imports are represented by a frying pan/lid of mainland type (Forsén 1996: 80, cat. no. 8) in a Volcanic (class: fresh well sorted) fabric. It may be significant that saddle querns and mortars from the valley dating to the $\mathrm{EH}$ period include examples made of sandstone and andesite (Forsén 1996: fig. 27). Sandstone (class: sparse in very fine sand matrix) continued to be used in EH II, occurring in a keyhole hearth (Forsén 1996: 105, cat. no. 132) characteristic of this phase. Felsic (class: silt-extremely fine) fabrics also appear in characteristic EH II fineware: a sauceboat, incurving-rim bowl, and ladle. Several EH fabrics contain mudstone temper, which is a feature of compositions seen in later periods (TABLE 2) and may be comparable to siltstone fabrics reported from the southern Argolid (Myer, Betancourt, and Vaughan 1995; Shriner and Dorais 1999). Two hemispherical bowls and two keyhole hearths from findspots FS 39 and FS 414 (Forsén 1996: 87, 89, 98, cat. nos. 40, 53, 54, 95) with Mudstone (class: siltstone limestone) fabrics contain mudstone with a distinctive turbid internal structure probably from a common source. The mudstone is probably temper (i.e., intentionally added) as it occurs in both red- and yellow-refired clays. External contacts remain evident in the occurrence of Volcanic fabrics, notably a pithos sample from findspot FS 12 (Forsén 1996: 105, cat. no. 126), located high in the mountains.

\section{Middle and Late Helladic}

Apart from the Mastos there is scant evidence for extensive population in the valley during the Middle Helladic (MH) (Wells 1996b) and early Late Helladic (LH) periods (Schallin 1996). Pottery of the later LH IIIA2-IIIB1 period (ca. I375-I225 B.C.) is, by contrast, widely distributed across the valley, especially in western areas, representing a rapid expansion in agricultural activity. This was undoubtedly a direct result of developments at Mycenae, which was a flourishing palatial center at this time. Occupation of the valley subsequently diminished with scant remains of $\mathrm{LH}$ IIIB2-IIIC (ca. I225-IO5O B.C.) material, mirroring contemporary destructions at Mycenae.

Almost all $\mathrm{MH}$ and $\mathrm{LH}$ samples come from excavations at the Mastos, primarily from the kiln site, and include several over-fired pieces. MH samples belong to the Mudstone group and most refired yellow. Limited sampling probably accounts for the absence of Felsic and possibly other fabrics (cf. Whitbread 2001) from this period. Most LH samples are fine-grained Felsic (class: silt-extremely fine) and refired yellow, which is typical for Mycenaean

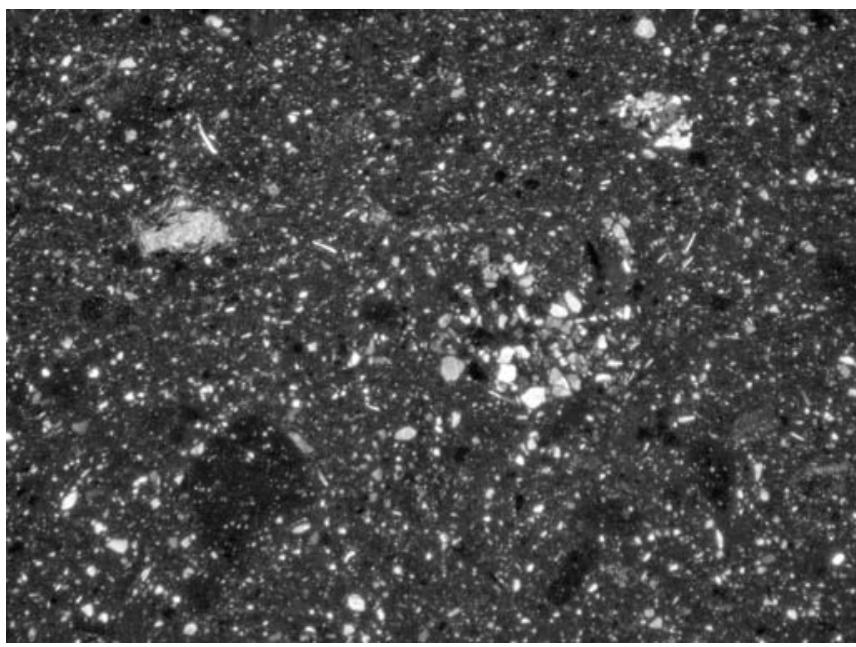

Figure 3. Photomicrograph of Sandstone (class: sparse in very fine sand matrix) from a Middle Neolithic bowl (FS 400; Johnson 1996: 50 , cat. 14), crossed polars, width of field is $3.7 \mathrm{~mm}$. Note the sandstone inclusion (center right).

pottery in the region. Coarseware continued to be made of Mudstone fabrics that refired yellow. Organic material was used in functionally specific fabrics, such as the drainage channels, e.g. Mudstone (chaff). This period sees a shift towards the use of clay that refired yellow (TABLE 2), and there may be a technological preference for coarseware with Mudstone fabrics and fineware with Felsic fabrics.

\section{Late Geometric and Archaic}

Following the collapse of the Mycenaean palatial system there is little sign of occupation in the valley until the mid8th century B.C. (Wells 1996c). Though probably correct (Penttinen 2005: 12), this impression may also reflect limitations in ceramic chronologies for the region (Ekroth 1996). Remains are concentrated around the Kephalari Rema ravine (FIG. I), on the communications route from Mycenae. Samples come from farmsteads (FS 20, FS 24), a cist grave (FS 402), the Mastos, and excavations at the cult location by a Mycenaean tholos tomb (FS 516) (FIG. I) (Wells, Ekroth, and Holmgren 1996).

Stylistically, most Late Geometric period material is considered to be imported from the Argos Plain (Ekroth 1996) to the south, though local production remains a possibility. Ekroth identified two Geometric fabrics in hand-specimens, both of which are hard and fine-grained with calcareous inclusions: fabric $\mathrm{A}$ is smooth and very pale brown, Fabric B is compact and pink to reddish yellow with cavities. Microscopically almost all Geometric samples are Felsic (class: very fine sand), though samples refired red and yellow indicating the use of different clays. 


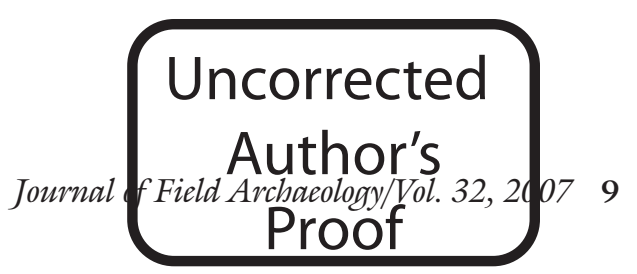

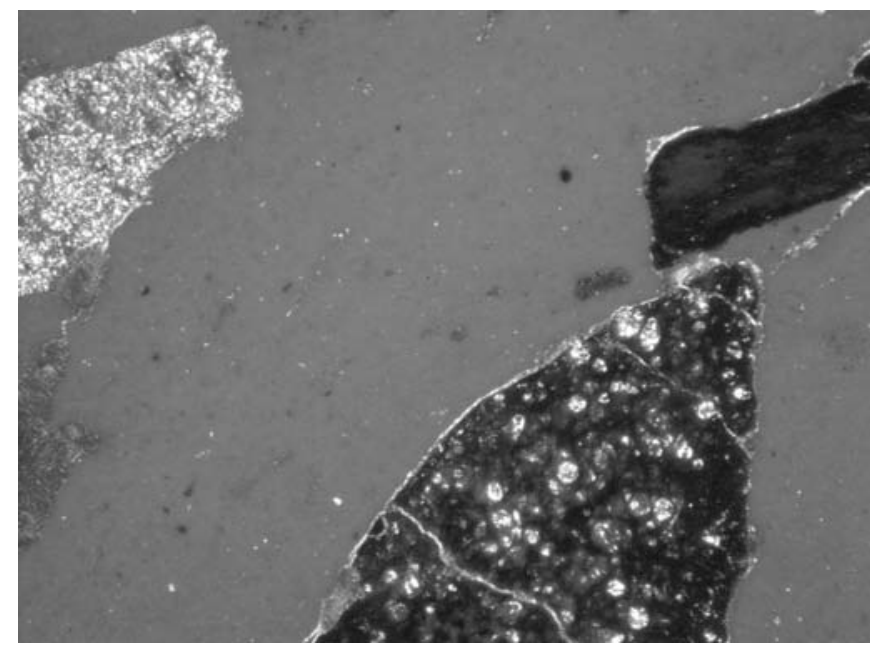

Figure 4. Photomicrograph of a Mudstone fabric with extremely fine matrix from a Classical wedge-shape kiln support (Pyrgouthi, sample 125), crossed polars, width of field is $3.7 \mathrm{~mm}$. Note the two mudstone inclusions (right) and the chert inclusion (left).

The hand-specimen fabrics do not correlate with the refiring results, probably owing to variation in the ancient firing conditions. Archaic period samples are likewise dominated by fineware in Felsic (class: very fine sand). Four coarseware samples, comprising two cooking pots, a relief phiale (Archaic) (Ekroth 1996: 202, cat. no. 89), and a hydria (probably Late Geometric) belong to the Mudstone group and refired red. The two cooking pots (Archaic) have distinctive close packed and well sorted Mudstone (class: quartz sand and breccia) fabrics, possibly for thermal shock resistance.

Scarcity of material and the predominance of fineware severely limit petrographic comparisons in this period and origins cannot be chemically determined without secure control groups. Use of Mudstone fabrics for coarseware echo practices in Corinth (Ekroth 1996), a major center of ceramic production in the latter part of this period, where yellow-firing clays were preferred (Whitbread 1995: table 5.2). The red-firing clays used for wares in the Berbati Valley therefore point to production elsewhere, either locally or possibly in the Argos Plain. EH III Siltstone fabrics from Lerna, a site to the sw (Myer, Betancourt, and Vaughan 1995: 677), which may be comparable to the Berbati Valley Mudstone fabrics, were fired gray to brown suggesting that fabrics with mudstone and red-firing clays are likely to have been produced in the Argolid albeit during an earlier period.

\section{Classical and Hellenistic/Early Roman}

No significant material distinctions exist between the
Classical and Hellenistic/Early Roman periods in the valley (Penttinen 1996). There is very little evidence for late Archaic and early Classical settlement, but recolonization by Argos in the mid 5th century B.c. introduced a new community, notably in the north-central area of the valley (Penttinen 1996: table 1, 2005: 108), in the area between findspots FS 400 and 503 (FIG. I), and development of an independent community at Mycenae (ca. 300 B.c., Penttinen 1996, 2005: 112) promoted considerable resettlement.

Classical pottery can be assigned to the Felsic and Mudstone groups, with most samples coming from excavations at Pyrgouthi (FIG. I), dating from the mid 5th century B.C. Two 5th century ceramic kilns were found there (Penttinen 2005: 20-36), as indicated by kiln supports recovered in the survey. This kiln furniture was sampled as a control for local fabrics. In all, four distinct ceramic traditions are represented in the Classical period. Red-refired fabrics are Felsic (class: silt-extremely fine), similar to Corinthian blisterware (Whitbread 1995: 305), with coarser Felsic fabrics used for utilitarian and cooking wares. Yellow-refired fabrics are Felsic (class: silt-extremely fine), used for tableware, and Mudstone (class: fine sand-extremely fine matrix) for tiles, utilitarian pottery and kiln supports (FIG. 4). These yellow-refired Mudstone fabrics are probably tempered, and bear a strong similarity to Corinthian products (Whitbread 1995: 294-304), although the kiln furniture demonstrates local production. The Clay-pellet fabrics form a distinct functional group. The Clay-pellet group (class: highly calcareous) includes daub (?) and clayey material from inside a kiln-related cutting, possibly reflecting reuse of the kiln area. Clay-pellet (class: red clay-pellets in silty matrix) occurs in a mudbrick (?) sample. These results suggest that different resources may have been exploited in building construction compared with pottery production. Hellenistic to Early Roman fabrics mainly refired red and belong to Felsic and Mudstone groups. Sandstone fabrics (not seen in the data set since the Early Bronze Age) also occur in utilitarian ware, notably beehives and an Early Roman amphora. Fabrics of the Classical and Hellenistic period are therefore consistent with locally available raw materials, bearing out Penttinen's (1996) observation on the scarce evidence for imports.

\section{Roman}

There is little evidence of occupation during the late Hellenistic and Early Roman periods, though this may reflect limited knowledge of ceramic repertoires (Penttinen 2005: 116) as much as changes in settlement resulting from the Roman annexation of Greece (Alcock 1993: 72-80). Although the Roman material dates from the 
1st-6th centuries A.D., most of it belongs to the Late Roman period of the 4th century, as with other regions of Greece (Forsell 1996; Alcock 1993: 72). A bath in the center of the valley is part of a substantial villa rustica (findspots FS 500-504) of the late 3rd to early 4th centuries with associated structures for olive oil production. Roman material, probably from farmsteads, also occurs in the NW part of the valley (Forsell 1996).

Felsic fabrics dominate the Late Roman period samples and there is a striking use of red-firing clays with chert inclusions. Felsic (class: chert limestone garnet) fabrics were used for a wide range of utilitarian wares (FIG. 5), including folded rim bowls like examples common at Corinth in the 4th-6th centuries (Forsell 1996: 322, cat. no. 118). Indeed similar fabrics, as observed in hand specimens, occur at Corinth and become increasingly common towards the Late Roman period (e.g. Williams and Zervos 1982: 138, cat. no. 67-69; Kathleen Slane, personal communication, 2005). As with Classical fabrics, similarities with Corinthian material mean that importation cannot be ruled out. In this case there is no direct evidence of local production, but Clay Samples 3, 12, and 14 are petrographically identical to ceramics with Felsic (class: chert limestone garnet) fabrics, suggesting that potters working for the villa used local resources. Architectural and utilitarian ceramics may also have been made in local fabrics since spacer pins and a drain pipe associated with the villa bath (Forsell 1996) have Felsic (class: quartz limestone) and Mudstone (class: limestone) fabrics. Clay-pellet (class: red clay-pellets in silty matrix) fabrics similar to the Classical mudbrick (?) are also present in two amphora stands.

\section{Late Antique}

The 6th and 7th centuries A.D. are what some researchers would call the Late Roman or Early Byzantine period. Owing to the cultural hybridization evident in the Berbati Valley at this time, Hjohlman (2005: 128) has argued that the period is better referred to as Late Antique. Samples from this period mainly come from excavations at the Pyrgouthi farmstead, dating from at least the second half of the 6th to the middle of the 7th centuries, a period of relatively dense rural habitation in Greece (Hjohlman 2005: 128). The fabrics continue Late Roman practices, and can be assigned to the Felsic, Mudstone, Sandstone, and Clay-pellet groups. Felsic (class: chert limestone garnet) fabrics dominate the utilitarian wares, i.e. Hjohlman's (2005: 236-238) medium coarseware and coarseware hand-specimen fabrics. The remaining fabrics are mainly from pithoi and tiles. Two tiles belong to the Clay-pellet (class: large fine clay-pellets) group (FIG. 6), which is the same fabric class as eight samples of construction material

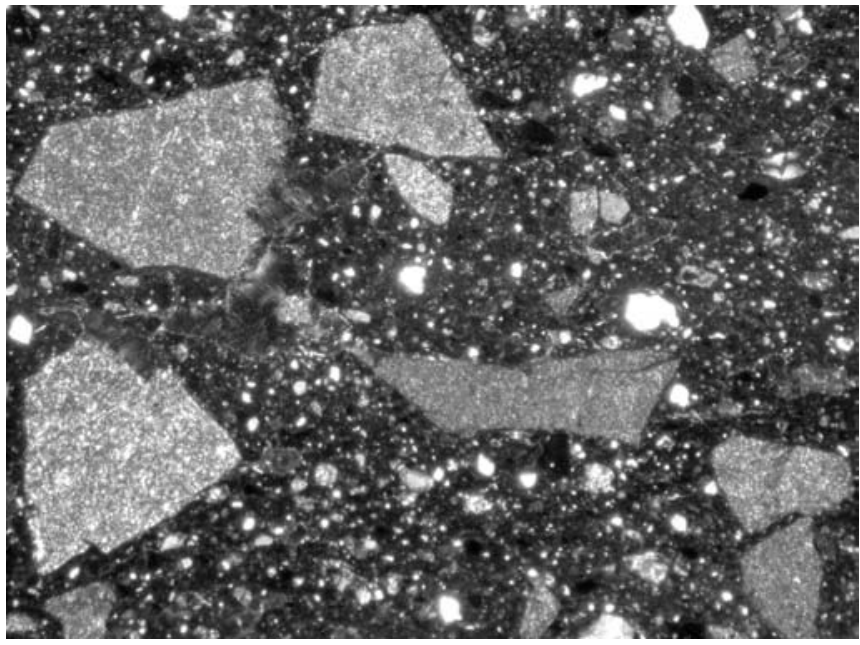

Figure 5. Photomicrograph of Felsic (class: chert limestone garnet) from a Late Roman basin (Findspot FS 504, sample 165), crossed polars, width of field is $3.7 \mathrm{~mm}$. Note the large, angular chert inclusions.

from the Late Antique tile kiln excavated by the Greek Archaeological Service (Hjohlman 2005: 241) and included in Table 2. Thus three, possibly four, Late Antique traditions may reflect functional differentiation, with Felsic (class: chert limestone garnet) fabrics for utilitarian ware, Clay-pellet (class: large fine clay-pellets) and Sandstone (class: red clay pellets-sandy) fabrics used for tiles, and Mudstone fabrics for pithoi and tiles.

\section{Medieval to Modern}

This period runs from the 8th century A.D., incorporating material of the Middle and Late Byzantine periods, to A.D. 1700 after which the village of Berbati was re-located to its present position. The valley was sparsely occupied from A.D. 700-1100. Extensive occupation developed towards the end of this period, but declined after ca. A.D. 1400 as settlement nucleated in the modern villages (Hahn 1996). No direct evidence of ceramic production was found, but a possible lining from the modern kiln destroyed in 1987 (Hahn 1996: 352, cat. no. 7), an overfired and distorted handle and a loom weight similar to an unfinished example (Hahn 1996: 415, 422: cat. nos. 176, 218) from the survey material were sampled.

Felsic, Mudstone, Sandstone and Clay-pellet groups continue to occur, including Felsic (class: chert limestone garnet) and Felsic (class: quartz limestone). The possible kiln lining and loom weight have Felsic (class: silt-extremely fine) and Felsic (class: fine sand) fabrics, which refired yellow and red respectively. Mudstone fabrics refired yellow and red, the latter including the Mudstone (class: 


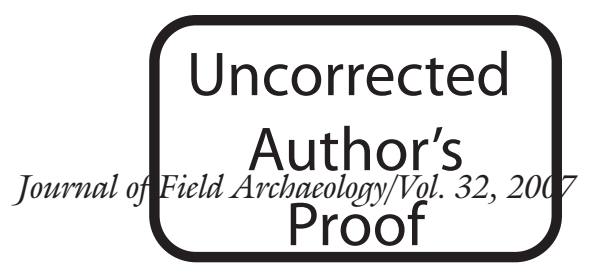

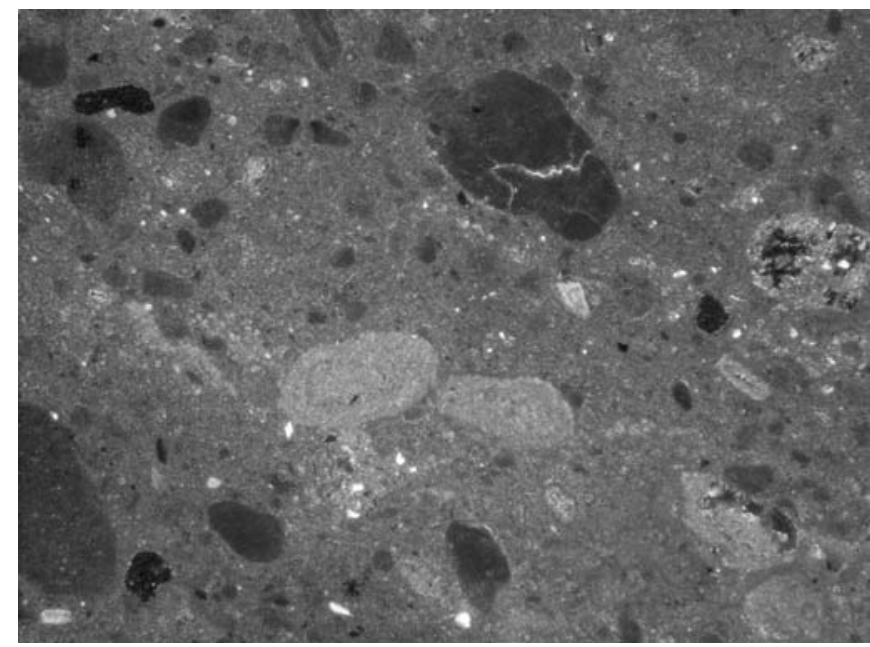

Figure 6. Photomicrograph of Clay-pellet (class: large fine clay-pellets) from a Late Antique tile (Findspot FS 500, sample 181), crossed polars, width of field is $3.7 \mathrm{~mm}$. Note the well rounded clay-pellets distributed throughout the fabric.

siltstone limestone) fabric of the over-fired handle. Sandstone (class: sparse in very fine sand matrix) occurs in a range of utilitarian wares, particularly from the 13th/14th centuries A.D. Clay-pellet (class: red silty clay-pellets) is present in two bowls and a cooking pot.

Sampling also sought to test Hahn's (1996) hand-specimen fabric classification for this period, with notable differences in results from the two analytical procedures. Hand-specimen fabrics $1,2,3$, and 5 were mainly variations on the Sandstone (class: sparse in very fine sand matrix) fabric. In contrast, Hand-specimen Fabrics 3 and 4 were thought likely to be the same, but were attributed microscopically to the Sandstone and Clay-pellet groups. Such differences in hand-specimen and microscopy results are not uncommon and reflect the greater resolving power of laboratory-based methods.

\section{Summary}

Petrographic analysis identified several fabric groups and classes in the Berbati Valley. Apart from the Volcanic group all of these fabrics could have been produced within the valley to judge by the local geology, although this does not rule out the possibility that some were imported. The limited numbers of samples from each cultural phase means that only broad trends can be firmly identified, but patterns in raw material procurement and use have emerged. The most conspicuous result is the apparent preference for some fabric groups compared to others. The Felsic and Mudstone groups occur throughout most of the cultural phases in the study (TABLE 2), but the Sandstone and Clay-pellet groups occur only intermittently. This result can be further explored at the level of fabric classes, which represent specific raw materials, used singly or in combination, and their methods of processing by the potters. Certain classes appear to have been preferred by potters in several cultural phases, notably Felsic (classes: chert limestone garnet, very fine sand, and silt-extremely fine), Mudstone (class: fine sand-extremely fine matrix), Sandstone (class: sparse in very fine sand matrix), and Clay-pellet (class: large fine clay-pellets). From these results it is evident that the full range of raw materials in the valley was not exploited in each cultural phase, perhaps reflecting the technological traditions of potters working in different settlement phases or changing patterns of raw material viability. The preference for specific fabric classes, despite major changes in the settlement of the valley, indicates that certain combinations of raw materials may be particularly effective in ceramic production or that these materials were little affected by different potters' methods of processing.

The most striking temporal change is the adoption of Felsic (class: chert limestone garnet) in the Roman and Late Antique periods. A Late Helladic preference for yellow-refired fabrics is also recognizable, especially compared with the use of both red- and yellow-refired clays in preceding and succeeding periods. Other shifts in raw material preferences may be evident, such as the use of Sandstone and Felsic fabrics in the Neolithic, Sandstone (class: sparse in very fine sand matrix) and Mudstone (class: siltstone limestone) fabrics in the Early Helladic, and Mudstone (class: quartz sand and breccia) for Archaic cooking pots, but sample numbers are too small to draw conclusions about these fabrics at this stage. Instead, these results offer avenues for further research on ceramic fabrics in the region.

\section{Chemical Analysis}

The petrographic results are based on compositions of rock and mineral inclusions rather than on the clay fraction of the fabrics. Chemical analysis was therefore carried out to incorporate the clay component in fabric characterizations, especially to clarify distinctions between calcareous and non-calcareous clays and to aid comparison of the pottery samples with clay samples collected in the valley.

Chemical analysis was conducted on the clay samples and pottery samples from the following periods: $\mathrm{MH}(6$ specimens), LH (16), Geometric (4), Archaic (2), Classical (18), Hellenistic (5), Roman (3), and Late Antique (16). When their calcium and iron concentrations are compared (FIG. 7) the results show a division into two groups: a high calcium $(>10 \% \mathrm{CaO}$ ) group and a low calcium $(<10 \%$ $\mathrm{CaO}$ ) group. In most cases these groups correspond to the 


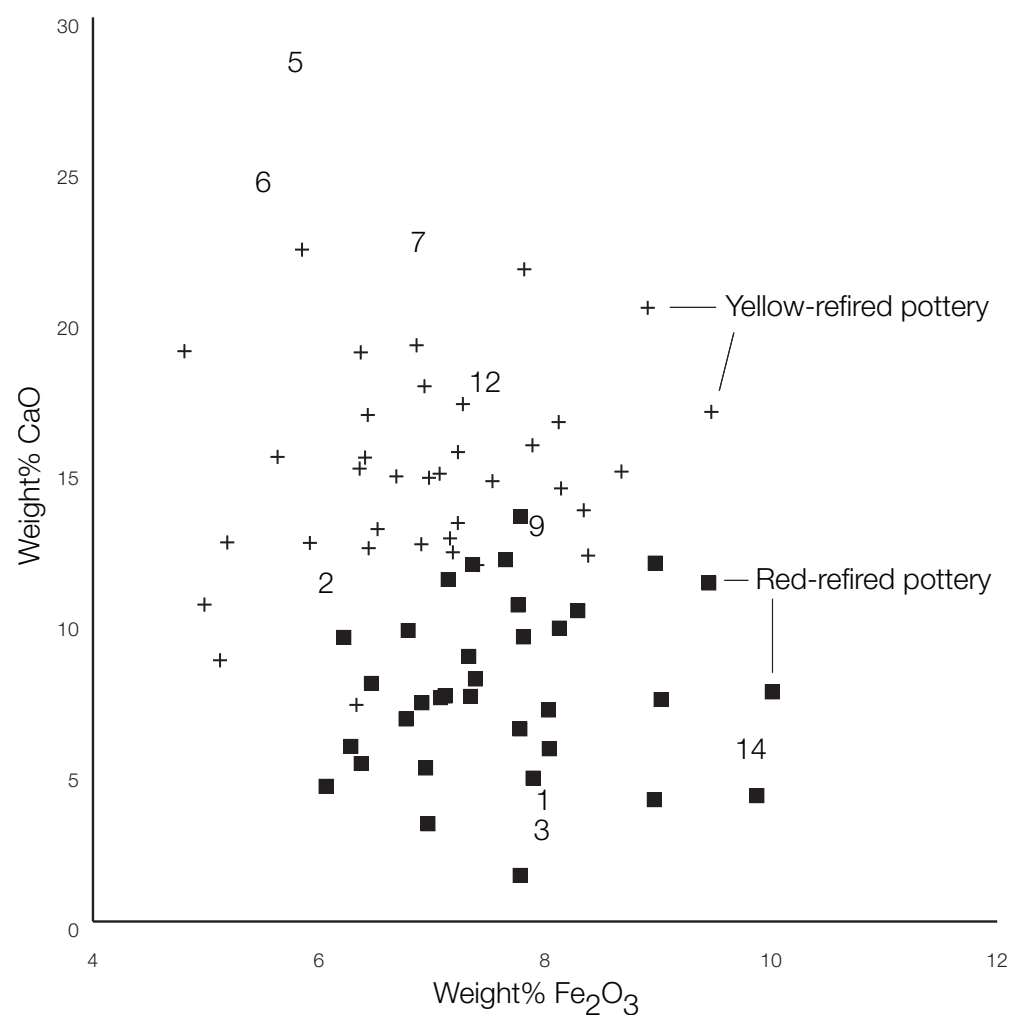

Figure 7. Scatter plot of the calcium and iron contents of ceramic samples compared with their refired colors. Fired clays from the valley are labeled with their sample numbers. Yellow-refired fabrics have higher concentrations of $\mathrm{CaO}$ (calcareous) compared to red-refired fabrics (non-calcareous).

yellow- (calcareous) and red- (non-calcareous) refired colors of the pottery samples and the fired colors of the clay samples. The nine clay samples fit into this picture reasonably well except for Clay Sample 12, having a Felsic (class: chert limestone garnet) fabric, which fires red, yet has a calcium/iron concentration that places it with yellow-refired sherds (FIG. 7). The likelihood of the pottery being made locally within the valley receives some support from these results, with the clay samples generally falling within the spread of the pottery samples. In two of the three yellowfiring clays (Clay Samples 5 and 6), calcium levels were significantly higher than in the pottery suggesting the use of different clays, dilution of these clays by the addition of temper and/or other clays, or merely leaching of calcium from the pottery during manufacture and subsequent burial (cf. Farnsworth, Perlman, and Asaro 1977).

Calcium and iron oxides are not the only components of clays, and interplay between minor and trace elements will also have an effect on properties, sometimes mitigating the effects of the main components. This is illustrated in the Principal Components Analysis results in which the graphical distribution of samples (FIGS. 8, 9) is calculated from correlations between all the analyzed elemental concentrations, excluding silica. The clustering of samples based on their chemical composition can be compared in terms of refiring results (FIG. 8) and chronology (FIG. 9). Figure 8 shows yellow-refired samples (calcareous) concentrated in the lower half of the graph. Red-refired samples (non-calcareous) dominate the upper half and overlap some of the yellow-refired samples. This result shows that the difference between red- and yellow-refired samples is still evident when elements in addition to calcium and iron oxides are taken into account, but the distinction is less obvious. In Figure 9 the same chemical distribution is presented in terms of two broad chronological ranges: in samples of Hellenistic or earlier date (including Middle and Late Helladic, Geometric and Classical) and in those of Roman and later periods (mainly Late Roman and Late Antique). The earlier samples dominate the lower part of the graph and the later samples are mainly restricted to the upper part. A comparison of Figures 8 and 9 shows that the Hellenistic and earlier fabrics sampled for chemical analysis comprise both red- and yellow-refired samples, but Roman and later samples are predominantly red-refired. The 

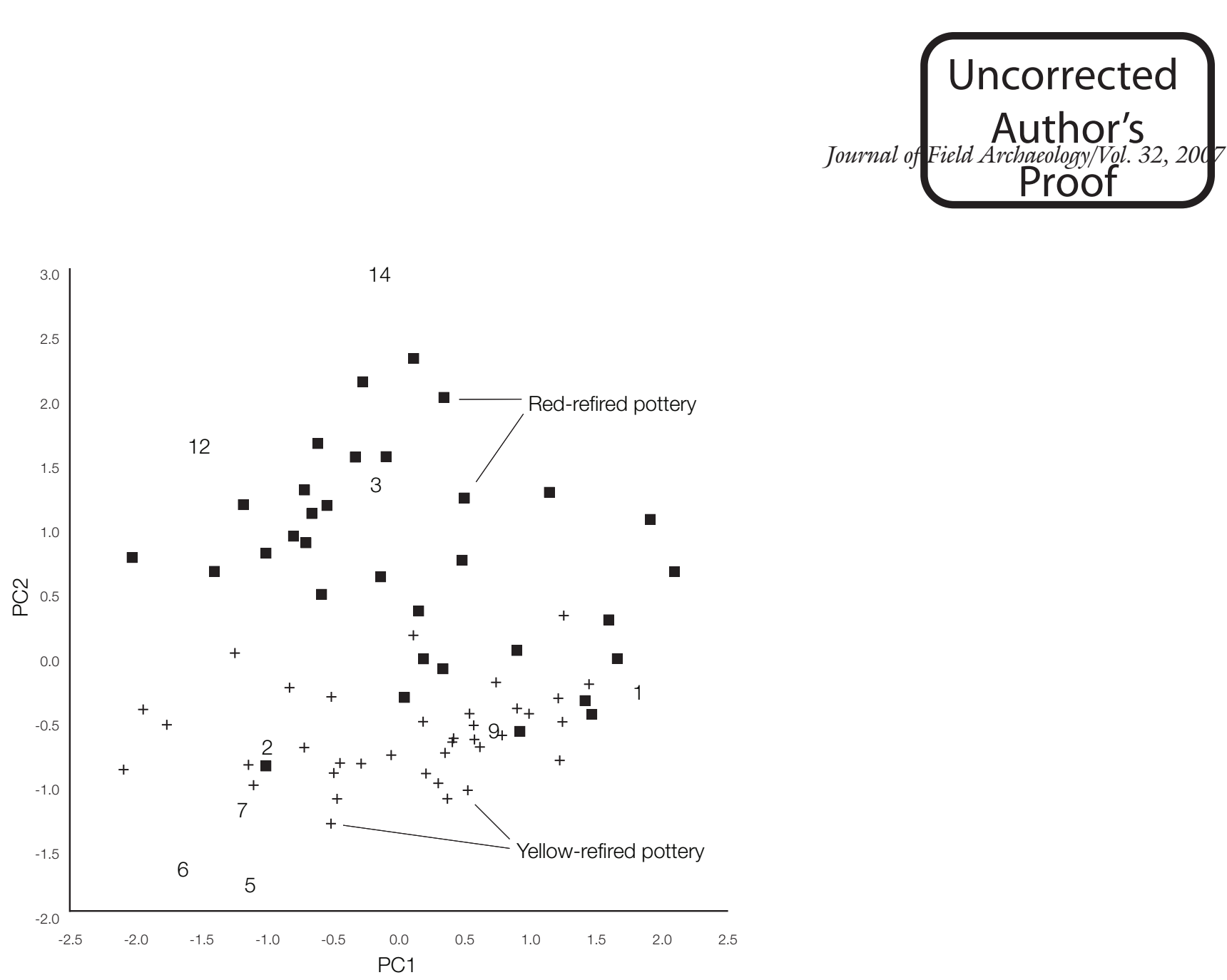

Figure 8. Principal Components Analysis plot of ceramic samples compared with their refired colors. Fired clays from the valley are labeled with their sample numbers. The distribution of samples is based on correlations of all elements analyzed (except silica). Yellow-refired and red-refired clusters can still be identified although there is overlap on the right side of the graph.

latter samples are mainly composed of Felsic (class: chert limestone garnet) fabrics and highlight the compositionally distinct nature of the raw materials used in the Roman and Late Antique periods in terms of both chemistry and petrography.

Yellow-firing Clay Samples 5, 6, and 7 fall to one side of the Hellenistic and earlier pottery (FIG. 9) suggesting that sampling missed the clays used to make yellow-firing Late Helladic (Mycenaean) pottery at the Mastos and Classical kiln supports at Pyrgouthi, though compositions of the latter may have been affected by the presence of mudstone inclusions. The two red-firing clays (Clay Samples 1 and 9) do have similar chemistry to the Mycenaean pottery, despite their firing color, but seem more likely to relate to the red-refired pottery of Classical and Hellenistic date that are also within this compositional field (FIG. 8). Clays sampled close to the Mycenaean kiln (Clay Samples 1, 2, and 14) do not fire yellow as preferred by the potters, which suggests that sampling either missed nearby sources of yellow-firing clay or that Mycenaean potters may have sought resources amongst the Pliocene-Pleistocene sediments to the Nw de- spite the weak association with yellow-firing Clay Samples 5,6 , and 7 from this area.

There is no observable distinction between the red-refired sherds of the Roman or Late Antique periods. The Felsic (class: chert limestone garnet) clays (Clay Samples 3, 12 , and 14) now all sit with the Roman and later material. Clay Samples 12 and 14 exhibit trace element characteristics markedly different from the other red-firing clays, containing significantly higher levels of chromium, manganese, cobalt, and nickel. These are elements commonly associated with iron minerals and indeed, Clay Sample 14 contains the highest levels of iron $\left(9.8 \% \mathrm{Fe}_{2} \mathrm{O}_{3}\right)$; however Clay Sample 12 contains no more iron than the other clays in the red-firing group. All three Felsic (class: chert limestone garnet) clays have different trace element characteristics, with Clay Sample 3 showing greatest similarity to the pottery.

\section{Discussion}

The evidence of ceramic manufacture in the Berbati Valley shows that local production certainly took place during 


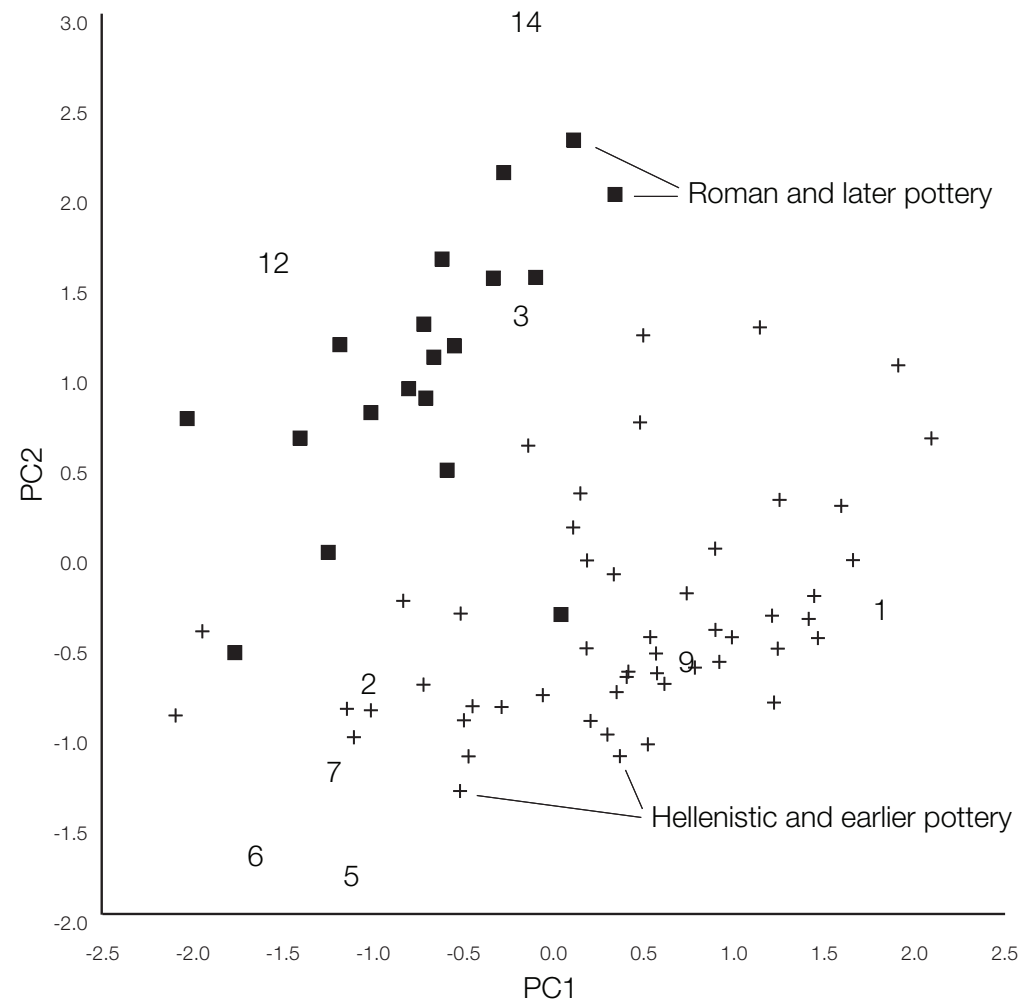

Figure 9. Principal Components Analysis plot of ceramic samples as shown in Figure 8 but labeled to compare Hellenistic and earlier pottery with Roman and later wares. Fired clays from the valley are labeled with their sample numbers. Compared with Figure 8, Hellenistic and earlier pottery comprises yellow and red-refired fabrics, but almost all Roman and later fabrics refired red and form a discrete cluster in the top left part of the graph.

some periods. Analysis of ceramics from the kiln sites has established that at least some Felsic (classes: silt-extremely fine and very fine sand), Mudstone (class: fine sand-extremely fine matrix) and Clay-pellet (class: large fine claypellets) fabrics are local products. Felsic (class: chert limestone garnet) fabrics could also be local on the basis of their similarity to clay deposits in the valley. The chemical compositions of Clay Samples 1, 2, 3, and 9 overlap with pottery samples (FIG. 9) and lend support to this interpretation. Unfortunately, the geological similarity of the valley to surrounding regions means that despite the production site evidence, imports may be undetected amongst what appear to be locally produced fabrics.

At the outset of this study we anticipated that raw materials best suited to ceramic production would be preferentially selected by potters. This inference has been supported by the petrographic analysis. Preferential selection of resources can be seen in the recurring use of Felsic and Mudstone fabrics (TABLE 2), most notably Felsic (classes: fine sand, very fine sand, and silt-extremely fine) and Mud- stone (class: fine sand-extremely fine matrix), and to a lesser extent in Sandstone (class: sparse in very fine sand matrix). This temporal pattern is partly evident in functional preferences (TABLE 3) in which Felsic, Mudstone and Sandstone fabrics occur in a wide range of wares, especially Felsic (class: chert limestone garnet), Mudstone (class: fine sand-extremely fine matrix) and Sandstone (class: sparse in very fine sand matrix).

We also proposed that changing settlement patterns may have introduced potters to the valley who worked in different technological traditions. The apparent settlement hiatuses, in some cases periods of nucleation, as determined in the Berbati Valley Survey (TABLE I) have allowed us to test this hypothesis. The difference between Sandstone and Felsic fabrics of the Middle and Late/Final Neolithic respectively is difficult to evaluate given the large time span and small number of samples. Similar problems affect comparisons of Early Helladic I and II fabrics. In contrast, settlements in the Middle to Late Helladic periods are more clearly marked by a preference for calcareous 


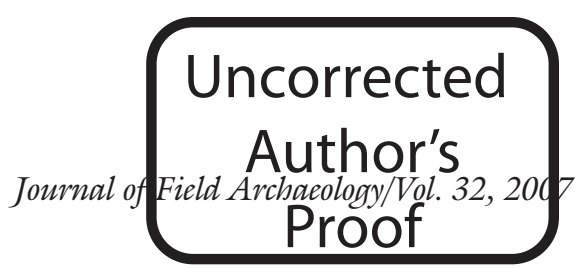

clays, tempered with mudstone in coarseware, especially when compared to the diverse range of Early Helladic fabrics. A subsequent change in raw materials appears in the Late Geometric and Archaic periods with both calcareous and non-calcareous clays being used, particularly red-refired Felsic (class: very fine sand) fabrics. This trend continued through the Classical and Hellenistic/Early Roman periods. Perhaps the clearest evidence for the introduction of potters with a different technological tradition is in the Late Roman period, with the adoption of the Felsic (class: chert limestone garnet) fabric. Its absence in earlier periods is particularly striking given the identification of this raw material in the limited clay sampling operation. The apparently sudden appearance of this fabric class may be attributed to the upsurge in Late Roman settlement activity (Alcock 1993: 72) and development of the villa rustica. At Corinth, where occupation was more consistent through the Roman period, there is a gradual adoption of apparently similar fabrics. Finally, a marked change in fabrics was not detected after the apparent hiatus of A.D. 700-1100, although again this may be due to the small number of samples in this period. This study has identified two key periods of change both in settlement and potters' technological traditions: Middle and Late Helladic, and Late Roman. It has also identified periods that may, through further sampling, show changes such as in the Neolithic and Early Helladic periods with respect to Sandstone fabrics, and in the Roman to Late Antique period in the use of Claypellet fabrics.

As is often the case with archaeological evidence, we lack the detailed information on social contexts that can aid investigations of technological traditions in some ethnographic studies (Neupert 2000; Stark, Bishop, and Miksa 2000). This makes it difficult to identify specific reasons behind these changes in procurement practices. One approach may be to focus on rural contexts in which significant changes in material culture can be traced over relatively short periods of time. By comparing the types of ceramic vessels found in rural sites in the Methana Survey, Foxhall (2004) has argued that distinct differences exist between the domestic assemblages of Classical and Hellenistic "farmsteads" compared with those of the Roman-Late Roman period. This is most evident in the higher proportions of coarseware, closed storage vessels, and amphoras on the Roman sites. Foxhall has interpreted this difference as reflecting a shift in emphasis from subsistence farming to agricultural production for a wider market. Such changes in landscape exploitation and their impact on ceramic repertoires may have caused adjustments in the organization of ceramic production that underlie the raw material preferences of Roman and later periods.
Only a few clay samples were collected in the valley, but they demonstrate both the limitations and advantages of comparing clays with ancient pottery fabrics. The weak chemical correlation between calcareous Clay Samples 5, 6, and 7 and the ancient pottery highlights the crucial role of kiln evidence in characterizing local production. Further sampling of clay beds may find a better compositional match but, as can be seen in the case of Felsic (class: chert limestone garnet) fabrics, the identification of raw materials in the field does not prove that local production took place, only that the potential existed. Clay sampling can provide significant insights into the technology of ceramic production. Chert inclusions in ceramics of the Felsic (class: chert limestone garnet) fabrics might be interpreted as having been crushed and added as temper owing to their uniform composition, coarse well-sorted grains and angular shapes (FIG. 5), but the presence of identical material in Clay Samples 3, 12, and 14 demonstrates that these are natural inclusions rather than temper.

\section{Conclusions}

This research program set out to examine the degree to which compositional analysis can identify temporal patterns in raw material exploitation based on pottery recovered in regional survey. It has demonstrated that sampling on a scale typical of many provenance-oriented studies can produce significant insights into raw material procurement patterns and provide a valuable point of departure for further research on specific periods or fabrics. In the Berbati Valley, sampling across several cultural phases has detected shifting preferences in raw materials, some of which appear to correlate with changes in settlement patterns. These settlement changes could have brought potters with different technological traditions into the valley, or settlement reorganization may have affected the viability of some sources, perhaps in terms of accessibility. Further research will be necessary to examine the reasons behind changes in procurement patterns, but the present study clearly demonstrates the diverse choices that potters of different cultural phases could make in exploiting the same geological landscape.

\section{Acknowledgments}

We thank the Greek Ministry of Culture, the 4th Ephorate of Prehistoric and Classical Antiquities at Nauplion, and the Institute of Geology and Mining Exploration for granting the permits for this study. Mrs Eleni Sarri of the 4th Ephorate of Prehistoric and Classical Antiquities at Nauplion generously allowed us to study material from the Late Antique kiln. Kathleen Slane (2005) is thanked for discussions on Roman pottery fabrics at Corinth. We thank 


\section{Temporal Patterns in Ceramic Production in the Berbati Valley/Whitbread, Ponting, and Wels Author's

the Gunvor and Josef Anér Foundation, Stockholm, for its support. Analyses were undertaken at the Fitch Laboratory, British School at Athens. We thank the reviewers for their advice on earlier drafts of this paper.

Ian K. Whitbread (Ph.D. 1987, University of Southampton, $U$. K.) has been engaged in the analysis of ceramic production and exchange in the Aegean since 1979, with particular focus on methodological issues in ceramic petrography. From 1992 to 2001 he was Director of the Fitch Laboratory, British School at Athens, Greece. He is a Lecturer in Archaeology at the University of Leicester. Mailing address: School of Archaeology and Ancient History, University of Leicester, University Road, Leicester, LE1 7RH, U. K. E-mail: ikw3@le.ac.uk Matthew. J. Ponting (Ph.D. 1994, University College, London) focuses on ancient metalwork, especially coinage alloys during the Roman period. From 1997 to 1999 he was Chemistry Fellow at the Fitch Laboratory, British School at Athens, Greece. He is Lecturer in Science-Based Archaeology at the University of Liverpool. Mailing Address: School of Archaeology, Classics and Egyptology, University of Liverpool, Brownlow Street, Liverpool, L69 3GS, U. K. E-mail: m.ponting@liverpool.ac.uk

Berit Wells (Ph.D. 1983, University of Lund, Sweden) has directed field programs since 1985 at Asine, Berbati, and Kalaureia in Greece, with particular emphasis on society and landscape archaeology. From 1991 to 1994 she was Assistant Director of the Swedish Institute at Athens and from then until 2003 was Director of the Institute. At present she is directing the investigations at the Sanctuary of Poseidon on Kalauriea. Mailing address: Tullgatan 7B, S-223 54 Lund, Sweden.E-mail: berit.wells@sia.gr

Åkerström, Åke

1968 "A Mycenaean Potter's Factory at Berbati near Mycenae." Atti e memorie del $1^{\circ}$ congresso internatzionale di micenologia Roma 27 setembre-3 ottobre 1967 1. Incunabula Graeca: 48-53.

Alcock, Susan E.

1993 Graecia Capta: The Landscapes of Roman Greece. Cambridge: Cambridge University Press.

2000 "Extracting Meaning from Plough Soil Assemblages: Assessments of the Past, Strategies for the Future," in Riccardo Francovich and Helen Patterson, eds., Extracting Meaning from Ploughsoil Assemblages. The Archaeology of Mediterranean Landscapes 5. Oxford: Oxbow Books, 1-4.

Arnold, Dean E.

1985 Ceramic Theory and Cultural Process. Cambridge: Cambridge University Press.

Dousougli, Angelika

1987 "Makrovouni-Kefalari Magoula-Talioti. Bemerkungen zu den Stufen FHI und II in der Argolis," Prähistorische Zeitschrift 62: 162-220.
Ekroth, Gunnel

1996 "The Late Geometric and Archaic Periods", in Berit Wells, ed., The Berbati-Limnes Archaeological Survey 1988-1990, Acta Instituti Atheniensis Regni Sueciae, Series 4 ${ }^{0}$, 44. Stockholm: Paul Åströms Förlag, 179-227.

Farnsworth, Marie, Isadore Perlman, and Frank Asaro

1977 "Corinth and Corfu: a Neutron Activation Study of their Pottery," American Journal of Archaeology 81: 455-468.

Forsell, Renée

1996 "The Roman Period," in Berit Wells, ed., The BerbatiLimnes Archaeological Survey 1988-1990. Acta Instituti Atheniensis Regni Sueciae, Series $4^{0}$, 44. Stockholm: Paul Åströms Förlag, 285-342.

Forsén, Jeannette

1996 "The Early Helladic Period," in Berit Wells, ed., The Berbati-Limnes Archaeological Survey 1988-1990. Acta Instituti Atheniensis Regni Sueciae, Series $4^{\circ}$, 44. Stockholm: Paul Åströms Förlag, 76-120.

Foxhall, Lin

2004 "Small, Rural Farmstead Sites in Ancient Greece: A Material Cultural Analysis," in Frank Kolb, ed., Chora und Polis, Schriften des Historischen Kollegs, Kolloquien 54. Munich: R. Oldenbourg Verlag, 249-270.

Gosselain, Olivier P.

1998 "Social and Technical Identity in a Clay Crystal Ball," in Miriam Stark, ed., The Archaeology of Social Boundaries. Washington, D.C.: Smithsonian Institution Press, 78-106.

Hahn, Margrete

1996 "The Early Byzantine to Modern periods," in Berit Wells, ed., The Berbati-Limnes Archaeological Survey 1988-1990. Acta Instituti Atheniensis Regni Sueciae, Series $4^{0}$, 44. Stockholm: Paul Åströms Förlag, 345-451.

Hein, Arno, Alexandra Tsolakidou, and Hans Mommsen

2002 "Mycenaean Pottery from the Argolid and Achaia-A Mineralogical Approach Where Chemistry Leaves Unanswered Questions," Archaeometry 44, 177-186.

Heyworth, M. P., John R. Hunter, Stanley E. Warren and John N. Walsh

1991 "ICPS of Glass: the Multi-element Approach," in Michael J. Hughes, Michael R. Cowell, and Duncan R. Hook, eds., Neutron Activation and Plasma Emission Spectrometric Analysis in Archaeology. British Museum Occasional Paper 82. London: British Museum, 143-154.

Hjohlman, Jenni

2005 "Pyrgouthi in Late Antiquity" in Jenni Hjohlman, Arto Penttinen, and Berit Wells, eds., Pyrgouthi. A Rural Site in the Berbati Valley in the Argolid from the Early Iron Age to Late Antiquity. Excavations by the Swedish Institute at Athens 1995 and 1997. Acta Instituti Atheniensis Regni Sueciae, Series $4^{0}$, 52. Stockholm: Paul Åströms Förlag, 127-266.

Johnson, Mats

1996 "The Neolithic Period," in Berit Wells, ed., The BerbatiLimnes Archaeological Survey 1988-1990. Acta Instituti Atheniensis Regni Sueciae, Series $4^{0}$, 44. Stockholm: Paul Åströms Förlag, 37-73.

Jones, Richard E.

1986 Greek and Cypriot Pottery: A Review of Scientific Studies, Fitch Laboratory Occasional Paper 1. Athens: British School at Athens. 
Kiriatzi, Evangelia

2003 "Sherds, Fabrics and Clay Sources: Reconstructing the Ceramic Landscapes of Prehistoric Kythera," in Karen P. Foster and Robert Laffineur, eds., Metron: Measuring the Aegean Bronze Age. Proceedings of the 9th International Aegean Conference, New Haven, Yale University, 12-21 April, 2002. Aegaeum 24. Liège: Université de Liège, 123-130.

Matson, Frederick R

1972 "Ceramic Studies," in William A. McDonald and George R. Rapp, Jr., eds., The Minnesota Messenia Expedition: Reconstructing a Bronze Age Regional Environment. Minneapolis: University of Minnesota, 200-224.

Millett, Martin

2000 "Dating, Quantifying and Utilizing Pottery Assemblages from Surface Survey," in Riccardo Francovich and Helen Patterson, eds., Extracting Meaning from Ploughsoil Assemblages. The Archaeology of Mediterranean Landscapes 5. Oxford: Oxbow Books, 53-59.

Moody, Jennifer, Harriet L. Robinson, Jane Francis, Lucia Nixon, and Lucy Wilson

2003 "Ceramic Fabric Analysis and Survey Archaeology: The Sphakia Survey," Anmual of the British School at Athens 98: 37-105.

Myer, George H., Philip P. Betancourt, and Sarah J. Vaughan

1995 "Appendix II. Petrography. A Ceramic Petrography of Selected Pottery Samples from Lerna IV,' in Jeremy B. Rutter, Lerna, A Preclassical Site in the Argolid. Results of Excavations Conducted by the American School of Classical Studies at Athens. Volume 3: The Pottery of Lerna IV. Princeton: The American School of Classical Studies at Athens, 666-693.

Neupert, Mark A.

2000 "Clays of Contention: An Ethnoarchaeological Study of Factionalism and Clay Composition," Journal of Archaeological Method and Theory 7: 249-272.

Penttinen, Arto

1996 "The Classical and Hellenistic Periods", in Berit Wells, ed., The Berbati-Limnes Archaeological Survey 1988-1990. Acta Instituti Atheniensis Regni Sueciae, Series $4^{0}$, 44. Stockholm: Paul Åströms Förlag, 129-283.

2005 "From the Early Iron Age to the Early Roman times," in Jenni Hjohlman, Arto Penttinen, and Berit Wells, eds., Pyrgouthi. A Rural Site in the Berbati Valley in the Argolid from the Early Iron Age to Late Antiquity. Excavations by the Swedish Institute at Athens 1995 and 1997. Acta Instituti Atheniensis Regni Sueciae, Series $4^{0}$, 52. Stockholm: Paul Åströms Förlag, 11-125.

Potts, Philip J.

1987 A Handbook of Silicate Rock Analysis. London: Blackie.

Runnels, Curtis

1996 "The Stone Artifacts from the Neolithic Period," in Berit Wells, ed., The Berbati-Limnes Archaeological Survey 1988-1990. Acta Instituti Atheniensis Regni Sueciae, Series $4^{0}$, 44. Stockholm: Paul Åströms Förlag, 41-43.

Säflund, Gösta

1965 Excavations at Berbati 1936-1937. Stockholm Studies in Classical Archaeology 4. Stockholm: Almquist and Wiksell.

Schallin, Ann-Louise

1996 "The Late Helladic Period," in Berit Wells, ed., The BerbatiLimnes Archaeological Survey 1988-1990. Acta Instituti Atheniensis Regni Sueciae, Series $4^{0}$, 44. Stockholm: Paul Åströms Förlag, 123-175.
Shriner, Christine, and Michael J. Dorais

1999 "A Comparative Electron Microprobe Study of Lerna III and IV Ceramics and Local Clay-Rich Sediments," Archaeometry 41: 25-49.

Stark, Miriam T., Ronald L. Bishop, and Elizabeth Miksa

2000 "Ceramic Technology and Social Boundaries: Cultural Practices in Kalinga Clay Selection and Use," Journal of Archaeological Method and Theory 7: 295-331.

Tataris, A. A., G. A. Kallergis, G. D. Kounis, and Georgos Christodoulou

1970 Geological Map of Greece, 1:50,000, Nafplion Sheet. Athens: Institute for Geology and Subsurface Research (I.G.M.E.).

van Dommelen, Peter

2000 "Post Depositional Effects and Ceramic Analysis: Comment on Jeremy Taylor, 'Depositional and Post-depositional Effects on Ploughsoil Ceramic Assemblages"' in Riccardo Francovich and Helen Patterson, eds., Extracting Meaning from Ploughsoil Assemblages. The Archaeology of Mediterranean Landscapes 5. Oxford: Oxbow Books, 27-28.

Wells, Berit

1996a "Introduction", in Berit Wells, ed., The Berbati-Limnes Archaeological Survey 1988-1990. Acta Instituti Atheniensis Regni Sueciae, Series $4^{0}$, 44. Stockholm: Paul Åströms Förlag, 9-22.

1996b "The Middle Bronze Age", in Berit Wells, ed., The BerbatiLimnes Archaeological Survey 1988-1990. Acta Instituti Atheniensis Regni Sueciae, Series $4^{\circ}$, 44. Stockholm: Paul Åströms Förlag, 121.

1996c "The Early Iron Age", in Berit Wells, ed., The BerbatiLimnes Archaeological Survey 1988-1990. Acta Instituti Atheniensis Regni Sueciae, Series $4^{0}$, 44. Stockholm: Paul Åströms Förlag, 177.

Wells, Berit, Gunnel Ekroth, and Kaj Holmgren

1996 "The Berbati Valley Project: The 1994 Season," Opuscula Atheniensia 21: 189-209.

Whitbread, Ian K.

1995 Greek Transport Amphorae: A Petrological and Archaeological Study, Fitch Laboratory Occasional Paper 4. London: British School at Athens.

2001 "Petrographic Analysis of Middle Bronze Age Pottery from Lerna, Argolid”, in Yannis Bassiakos, Eleni Aloupi, and Yorgos Facorellis, eds., Archaeometry Issues in Greek Prehistory and Antiquity. Athens: Hellenic Society of Archaeometry, 367-377.

Williams, Charles K., II, and Orestes H. Zervos

1982 "Corinth, 1981: East of the Theatre," Hesperia 51: 115-163. 